Bull. Chem. Soc. Ethiop. 2017, 31(1), 137-147.

ISSN 1011-3924

(c) 2017 Chemical Society of Ethiopia and The Authors

Printed in Ethiopia

DOI: http://dx.doi.org/10.4314/bcse.v31i1.12

\title{
A RATIONAL SYNTHESIS OF A NOVEL IMIDAZO[4,5- $f][1,10]$ PHENANTHROLINE TEMPLATED SCHIFF BASE: CHARACTERIZATION, PHOTOLUMINESCENCE AND DFT/TD-DFT STUDY
}

\author{
S. Karslığlu ${ }^{1}$, S. Demir ${ }^{2}$, H. Yılmaz ${ }^{3 *}$ and S. Gördük ${ }^{4}$ \\ ${ }^{1}$ Department of Chemistry, Faculty of Science, Karadeniz Technical University, \\ Trabzon 61080, Turkey \\ ${ }^{2}$ Department of Industrial Engineering, Faculty of Engineering, Giresun University, Giresun \\ 28200, Turkey \\ ${ }^{3}$ Department of Chemistry, Faculty of Arts and Science, Ondokuz Mayıs University, Samsun \\ 55200, Turkey \\ ${ }^{4}$ Department of Chemistry, Faculty of Arts and Science, Yildiz Technical University, Istanbul \\ 34210, Turkey
}

(Received July 31, 2015; revised August 6, 2016)

\begin{abstract}
A new imidazo[4,5-f][1,10]phenanthroline (imp) derivative imidazo- $\mathrm{N}^{5}, \mathrm{~N}^{6}$-bis $((4-(1 \mathrm{H}-$ imidazo[4,5-f][1,10]phenanthroline-2-yl)phenyl)methylene)-1,10-phenanthroline-5,6-diamine (impap) was synthesized in five steps starting from bare phenanthroline (phen) precursors. The novel compound was fully characterized by ${ }^{1} \mathrm{H}-\mathrm{NMR}$, IR, elemental analysis and electrospray ionization mass spectroscopy (ESI-MS) techniques. Solid state emission spectrum of impap showed two distinct strong emission maxima with large Stokes shifts. The ground state gas phase geometry of impap was predicted by DFT calculations. Excited state properties of the molecule were examined through TD-DFT calculations conducted at the optimized geometry. Responsible transitions for the strong fluorescence of impap were assigned to single component charge transfer transitions with large oscillator strengths based on the ground state calculated molecular orbital contributions.
\end{abstract}

KEY WORDS: Phenanthroline, TD-DFT, Photoluminescence, Stokes shift, 1,10-phenanthroline-5,6-dione, Imidazo[4,5-f][1,10]phenanthroline

\section{INTRODUCTION}

The syntheses of imidazo[4,5-f][1,10]phenanthroline (imp) (Scheme 1) and its derivatives started with the syntheses of phenanthrimidazoles by Steck and Day [1]. The subsequent explorations have gained an increasing prominence on the strength of their fruitful implementations such as various luminescent sensors or stimulants, pharmacological agents, photoactive materials of organic light emitting diode (OLED) devices and mesophasic ingredients of liquid crystals. More precisely imp derivatives, associated with their large Stokes shifts and luminescence lifetimes, have excellent photophysical applications such as efficient hole blocker and electron transporters in OLED materials and molecular switches [2-9]. They are available as multifunctional ligands in the construction of high order non-linear systems [1012]. They constitute versatile components of metallomesogens or behave as mesogenic phase without metal component in the design of liquid crystals [13-16]. In addition, they play key roles in spectroscopic biosensing of nucleic acids owing to site-selective and adaptive binding to DNA in intercalative mode and in the development of unique chemotherapeutics where they impact on the functions of DNA within cancerous cells [17-27]. Therefore, imp derivatives seem to attract much more interest with many attempts to synthesize and design new materials with the above-mentioned properties. These pivotal multifunctionalities stem essentially from their interrelated rigid flat and extended $\pi$-aromatic structures displaying high conjugation throughout the entire molecule. The researchers exploiting their planar natures are mainly

*Corresponding author. E-mail: hakan.yilmaz@omu.edu.tr 
focused on the stereo-selective binding affinity towards double stranded-DNA by an intercalative mode. Since almost emission-silent triplet excited states in organic moieties or MLCT states in metal complexes, are strongly perturbed upon intercalation of planar imp parts between base pairs of DNA. These interactions produce efficient luminescence signals leading them to be advertised as molecular light switches for nucleic acids [26, 28, 29]. The studies with respect to their extended conjugate- $\pi$ aromatic characters have been mostly on light emitting displays. Since their extended highest occupied molecular orbital (HOMO) - lowest unoccupied molecular orbital (LUMO) gap with relatively low LUMO energy as crucial characteristics make them promising candidates especially for modern OLED's [3-5, 30, 31].

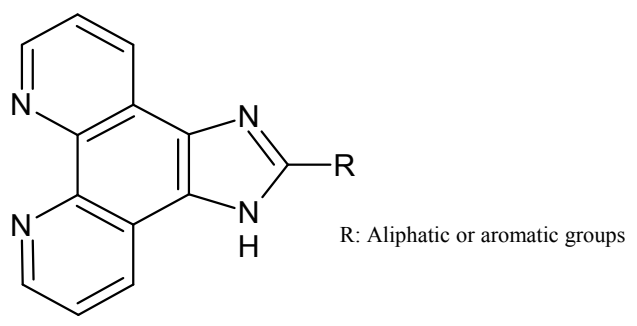

Scheme 1. General structure of imp derivatives.

There are numerous studies on organic compounds or metal complexes containing imp derivatives as functionalities that mainly account for the property of interest together with different groups or ancillary ligands. In this study, we report the synthesis of a new bulky and versatile member of imp family. The extended conjugate structure consists of imp moieties and 5,6-diamino-1,10-phenanthroline body. These imp moieties were symmetrically attached via terephthalaldehyde (tpa) connectors to 5,6-diamino-1,10-phenanthroline (dap) body which was also synthesized from 1,10-phenanthroline-5,6-dione as the same precursor with that of imp. The main compound was successfully characterized by ESI-MS, elemental analysis, ${ }^{1} \mathrm{H}-\mathrm{NMR}$ and IR spectroscopy techniques. The solid state photoluminescence measurement was carried out to simply show strong photoluminescent character of impap with an expected large Stokes shift and further probed excited states on theoretical viewpoint by means of DFT/TD-DFT calculations.

\section{EXPERIMENTAL}

\section{Materials and measurements}

All reagents and solvents were obtained from commercial suppliers and used without further purification unless otherwise specified.

Infrared spectra were measured with a Perkin-Elmer Spectrum-One FT-IR Spectrometer within $400-4000 \mathrm{~cm}^{-1}$ range using $\mathrm{KBr}$ pellets. ${ }^{1} \mathrm{H}-\mathrm{NMR}$ spectra were recorded in DMSO- $\mathrm{d}_{6}$ medium with a Varian Mercury $200 \mathrm{MHz}$ Spectrometer. Elemental analysis measurement was performed with a LECO CHNS Elemental Analyzer. ESI-MS spectrum was recorded in methanol with an AB SCIEX QTRAP ${ }^{\circ} 5500$ LC/MS/MS System Mass Spectrometer. The sample was dissolved in hyper grade DMF stirring in a Banderin Sonorex ultrasonic bath, and infusion (continuous signal) method with a flow rate of $5-20 \mu \mathrm{m} / \mathrm{min}$ was used for mass scanning. The photoluminescence spectrum for the solid sample was taken with a Perkin-Elmer LS-55 Spectrophotometer. 


\section{Computational protocol}

All computations were carried out using Gaussian 09 suit of programs running under Unix or Windows [32]. Geometry optimization was performed by using hybrid DFT/B3LYP functional within $\mathrm{C} 2$ symmetry constrain and subsequent TD-DFT calculation at the optimized geometry was performed for the first 70 vertical singlet excitations [31, 33, 34]. Double zeta 6-31G(d,p) basis set was used for geometry optimization while flexible LANL2DZ basis set was used for TD-DFT calculation [35-37]. Molecular orbital (MO) contributions of each transition were analyzed using Gaussian version 2.2 software package [38]. Simulated excitation profile was obtained using Swizard program version $4.7[39,40]$ with the Gaussian type fit (or lineshape or function) and taking the half-bandwidths, $\Delta_{1 / 2, \mathrm{I}}$, equal to $1500 \mathrm{~cm}^{-1}$.

\section{Synthesis of the compound}

The main compound was synthesized in a stepwise manner modifying the literature procedures as outlined. Step by step reactions of the compound are depicted in Scheme 2.

Synthesis of 1,10-phenanthroline-5,6-dione (Step 1). A well-ground mixture of $10.0 \mathrm{~g}$ (50 $\mathrm{mmol})$ phenanthroline monohydrate and $9.05 \mathrm{~g}(76.0 \mathrm{mmol}) \mathrm{KBr}$ in a round bottom flask fitting with a dropping funnel was mounted in a cooling bath at $-10{ }^{\circ} \mathrm{C}$. A mixture of $\mathrm{H}_{2} \mathrm{SO}_{4}(91 \mathrm{~mL}$, $96 \%)$ and $\mathrm{HNO}_{3}(42 \mathrm{~mL}, 65 \%)$ at $-78{ }^{\circ} \mathrm{C}$ maintained by ducking into liquid nitrogen was gently added to the first mixture during $30 \mathrm{~min}$. The resulting reddish-orange suspension was left undisturbed for cooling to room temperature (rt) and refluxed at $150{ }^{\circ} \mathrm{C}$ until bromine evolution to cease $(5-7 \mathrm{~h})$. The obtained yellow suspension was cooled to $\mathrm{rt}$, gradually poured into $1 \mathrm{~kg}$ ice, and $\mathrm{pH}$ of the mixture was raised up to 6 by adding $30 \% \mathrm{NaOH}$. The final yellow mixture was extracted with dichloromethane, dried on anhydrous $\mathrm{Na}_{2} \mathrm{SO}_{4}$, recrystallized from hot methanol, and dried in air [41]. Yield: $7.15 \mathrm{~g}(68 \%), \mathrm{mp} 257^{\circ} \mathrm{C}$.

Synthesis of 1,10-phenanthroline-5,6-dioxime (Step 2). A mixture of 1,10-phenanthroline-5,6dione (3.15 g, $15 \mathrm{mmol})$, hydroxylammonium chloride (3.65 g, $52.5 \mathrm{mmol})$ and barium carbonate $(4.44 \mathrm{~g}, 22.5 \mathrm{mmol})$ in $200 \mathrm{~mL}$ ethanol was refluxed for $12 \mathrm{~h} .300 \mathrm{~mL} 0.2 \mathrm{M} \mathrm{HCl}$ was added to the residue remained after the removal of the solvent and the mixture was further stirred for $30 \mathrm{~min}$. The resulting mixture was filtered and the pale yellow precipitate was washed with water, ethanol and ether respectively and dried in a vacuum oven at $80{ }^{\circ} \mathrm{C}$ [42]. Yield: 1.80 $\mathrm{g}(50 \%), \mathrm{mp} 231^{\circ} \mathrm{C}$.

Synthesis of dap (Step 3). $2.0 \mathrm{~g} \mathrm{1,10-phenanthroline-5,6-dioxime} \mathrm{(8.32} \mathrm{mmol)} \mathrm{and} 2.0 \mathrm{~g} \mathrm{Pd} / \mathrm{C}$ $(10 \%)$ were slurried in $250 \mathrm{~mL}$ anhydrous ethanol and after degassing with nitrogen, the mixture was refluxed for $1 \mathrm{~h}$. A mixture of hydrazine monohydrate $(18 \mathrm{~mL})$ and ethanol $(40 \mathrm{~mL})$ was added dropwise for $1 \mathrm{~h}$ to this solution and refluxed for $12 \mathrm{~h}$. The crude reaction mixture was filtered through celite using a crucible $(4 \mu \mathrm{m})$ to remove catalyst and washed four times with hot ethanol. The filtrate was brought to dryness with a vacuum evaporator and $120 \mathrm{~mL}$ water was added to the remainder. The solution was left for a night at $4{ }^{\circ} \mathrm{C}$. The resulting well-formed yellowish-brown precipitate was filtered, washed with cold water and dried in vacuum [42]. Yield: $0.77 \mathrm{~g}(44 \%), \mathrm{mp}>300^{\circ} \mathrm{C}$.

Synthesis of impal (Step 4). To a formerly prepared stirring mixture of $1.68 \mathrm{~g}$ 1,10phenanthroline-5,6-dione $(8 \mathrm{mmol})$, and $12.33 \mathrm{~g}$ ammonium acetate $(160 \mathrm{mmol})$ in $80 \mathrm{~mL}$ glacial acetic acid, terephthalaldehyde in acetic acid was added very gently to prevent instant excess diimine formation and the mixture was refluxed for $2 \mathrm{~h}$. The mixture was filtered while hot to separate slurry diimine by-product, the filtrate was cooled to $\mathrm{rt}$ and diluted with $300 \mathrm{~mL}$ 


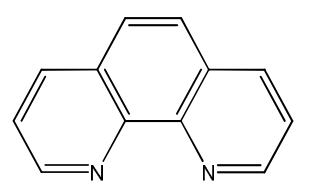

(1) $\underset{\mathrm{KBr}}{\mathrm{H} \mathrm{SO}_{4} / \mathrm{HNO}_{3}}$
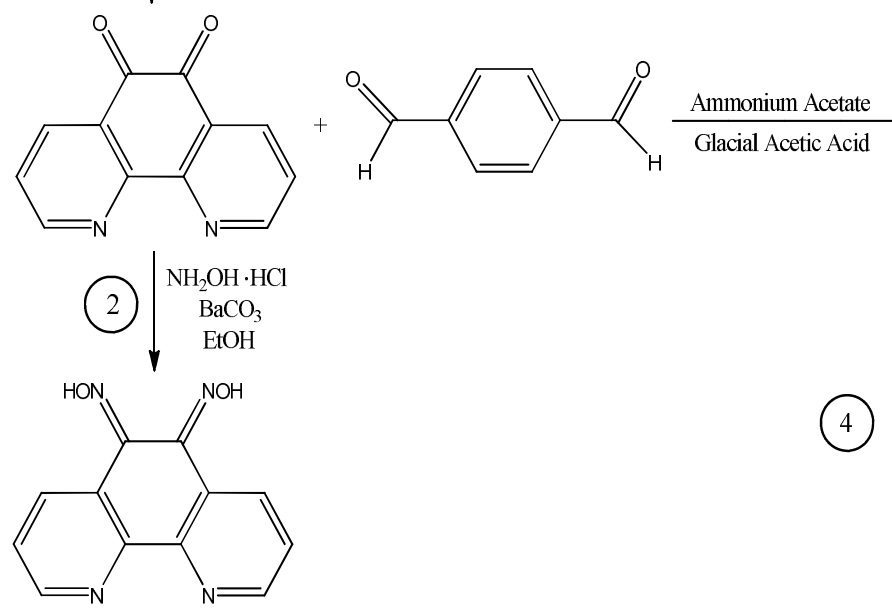

(3) $10 \% \mathrm{Pd} / \mathrm{C}$

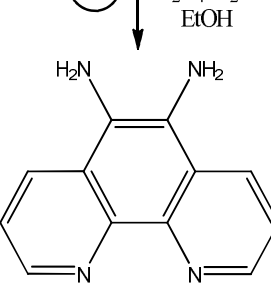

(5) EtOH

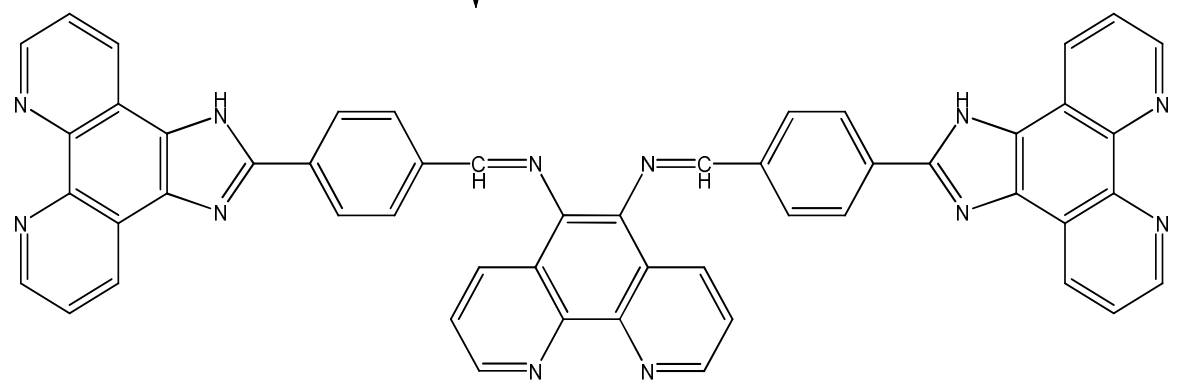

Scheme 2. Synthesis reactions of impap.

Bull. Chem. Soc. Ethiop. 2017, 31(1) 
distilled water. A yellow precipitate formed upon dropwise addition of concentrated ammonia to the solution was filtered, washed with water, dried in air and resolved in hot ethanol. The crystalline product formed upon cooling was filtered, washed with ethanol, water and ether, respectively and dried in vacuum $[1,12]$. Yield: $1.94 \mathrm{~g}(75 \%), \mathrm{mp}>300{ }^{\circ} \mathrm{C}$.

Synthesis of impap (Step 5). A $25 \mathrm{~mL}$ ethanol solution of dap (0.6 g, $2.85 \mathrm{mmol})$ was gradually added into a degassed stirring solution of impal $(1.85 \mathrm{~g}, 5.7 \mathrm{mmol})$ in ethanol. The mixture was refluxed for $4 \mathrm{~h}$ under nitrogen atmosphere, cooled to $\mathrm{rt}$, and filtered. The precipitate formed upon cooling was washed several times with hot ethanol and ether, and dried in a vacuum oven at $80{ }^{\circ} \mathrm{C}$. Yield: $1.52 \mathrm{~g}(65 \%)$, brown powder, $\mathrm{mp}>300{ }^{\circ} \mathrm{C}$. IR spectrum, $\mathrm{v}, \mathrm{cm}^{-1}: 3401 \mathrm{v}(\mathrm{N}-\mathrm{H})$; $3065 v(\mathrm{C}-\mathrm{H}) ; 1637 v_{\text {imine }}(\mathrm{C}=\mathrm{N}) ; 1606 v_{\text {phen }}(\mathrm{C}=\mathrm{N}) .{ }^{1} \mathrm{H}-\mathrm{NMR}$ spectrum $\left(200 \mathrm{MHz}\right.$; DMSO-d $\left.\mathrm{d}_{6}\right)$,

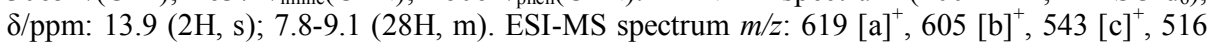
$[\mathrm{d}]^{+}, 501[\mathrm{e}]^{+}, 323[\mathrm{f}]^{+}, 310[\mathrm{~g}]^{+}, 296[\mathrm{~h}]^{+}, 234[\mathrm{i}]^{+}, 220[\mathrm{j}]^{+}, 180[\mathrm{k}]^{+}$. Found, \%: C 70.38; N 18.55; H, 4.98. Calculated (tetrahydrated form), \%: C 69.79; N 18.78; H 4.28.

\section{RESULTS AND DISCUSSION}

\section{Characterization}

Characteristic $-\mathrm{NH}_{2}$ stretching vibration of dap at 3371-3264 $\mathrm{cm}^{-1}$ and $-\mathrm{C}=\mathrm{O}$ stretching vibration of impal at $1697 \mathrm{~cm}^{-1}$ were not observed in IR spectrum of impap. Besides, appearance of $-\mathrm{C}=\mathrm{N}-$ stretching vibration at $1637 \mathrm{~cm}^{-1}$ instead of them clearly denotes to the formation of impap.

In ${ }^{1} \mathrm{H}-\mathrm{NMR}$ spectrum of impap, a broad singlet at $13.9 \mathrm{ppm}$ related to imidazolic protons and another peaks related to $\mathrm{CH}$ protons between 7.8-9.1 ppm were observed. The proximities of chemical shifts of $\mathrm{CH}$ protons and low frequency power of the instrument complicate the discrimination of them. On the other hand, integration rate (13.73) of imidazolic and $\mathrm{CH}$ protons indicates the formation of impap $(\mathrm{NH}, 2 \mathrm{H} ; \mathrm{CH}, 28 \mathrm{H})$. Also disappearance of aldehydic proton (s, $10.05 \mathrm{ppm}$ ) of impal in ${ }^{1} \mathrm{H}-\mathrm{NMR}$ spectrum of impap additionally supports the formation of the related product.

ESI-MS spectrum of impap most clearly verifies the formation of impap. Since peaks at $\mathrm{m} / \mathrm{z}$ : $619,605,543,516,501,323,310,296,234,220,180$ notated respectively with a, b, c, d, e, f, g, $\mathrm{h}, \mathrm{i}, \mathrm{j}$, k belong to fragmentation products of impap.

\section{Ground state structure and MO analysis}

The geometry of impap was optimized and verified for global minimum by subsequently performed frequency analysis having no imaginary frequency. Optimized structure of impap with C2 constrained symmetry is depicted in Figure 1.2-(4-formylphenyl)imidazo-[4,5$f][1,10]$ phenanthroline (impal) fragments of the molecule are trans oriented reciprocally at the optimized geometry and in these units, imp and tpa fragments are placed coplanar solely with a torsion of $0.713^{\circ}$. It can be said that the planarity of impal units is the major effect which produces large conjugation that also reflects strong fluorescence with large Stokes shift. A complete planarity of impap seems impossible owing to steric repulsion of imine hydrogens. Ground state MO contributions of frontier, the first two low and high lying MOs from the groups are given in Table 1 and their contourplots are depicted in Figure 2. As inferred from Table 1, HOMO is mainly localized on phen moiety and comprises equal contributions from tpa and imp parts while the LUMO comprises the largest contribution from tpa. HOMO-1 and HOMO-2 are composed mainly of imp and HOMO-3 completely resides on phen with none of contribution from the others. LUMO+1 spreads over the entire molecule with the largest 
contribution from tpa. Interestingly, $\mathrm{LUMO}+2$ and $\mathrm{LUMO}+3$ are completely degenerate and reside completely on impap.

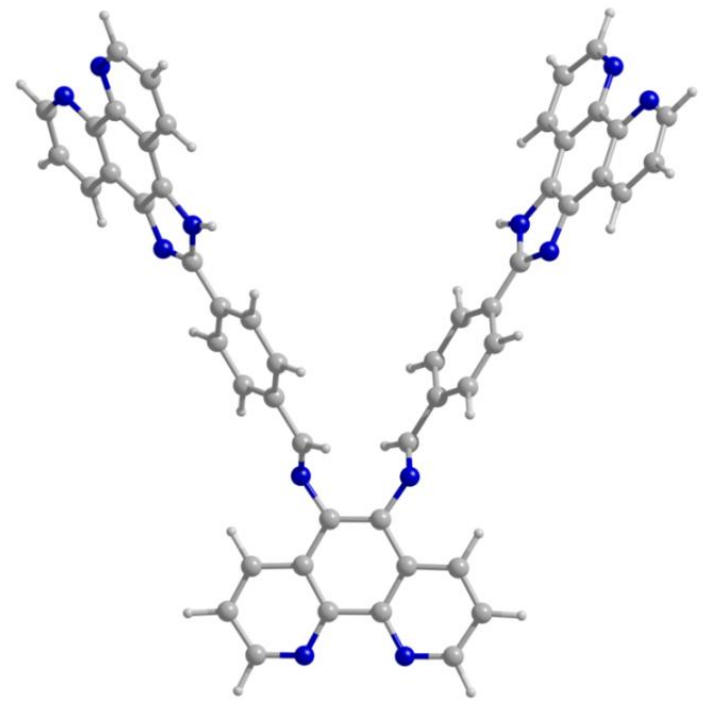

Figure 1. Geometry optimized structure of impap.

Table 1. Ground state MO contributions in impap from the selected groups.

\begin{tabular}{|c|c|c|c|c|c|c|c|c|}
\hline MO & $\mathrm{H}$ & $\mathrm{H}-1$ & $\mathrm{H}-2$ & $\mathrm{H}-3$ & $\mathrm{~L}$ & $\mathrm{~L}+1$ & $\mathrm{~L}+2$ & $\mathrm{~L}+3$ \\
\hline $\mathrm{E}(\mathrm{eV})$ & -5.51 & -5.82 & -5.94 & -6.45 & -2.41 & -2.2 & -1.5 & -1.5 \\
\hline $\mathrm{imp}$ & 20 & 80 & 63 & 0 & 19 & 25 & 100 & 100 \\
\hline tpa & 18 & 16 & 12 & 0 & 54 & 55 & 0 & 0 \\
\hline phen & 62 & 4 & 25 & 100 & 27 & 20 & 0 & 0 \\
\hline
\end{tabular}

Emission spectrum and TD-DFT excited states

In order to specify the origin of the excited states responsible for the experimental emission spectrum of imp and to express percentage MO compositions of them, the calculated transitions were considered to take place between ground state Kohn-Sahm MOs. Emission spectrum of impap as shown in Figure 3 displays two distinct emission maxima at $535 \mathrm{~nm}$ and $588 \mathrm{~nm}$ upon excitation at $387 \mathrm{~nm}$ where the strongest absorption occurs.

The first broader emission maximum cannot be attributed to any excimer formation even in solid state since it takes place at lower wavelength. Calculated excited state parameters of impap with non-zero oscillator strengths are given in Table 2.

The transitions with the largest oscillator strengths occur at higher wavelengths above 360 $\mathrm{nm}$ and are almost related to single MO transition with contributions over $90 \%$. The first excited state with an oscillator strength of 0.3705 is of almost pure $\mathrm{HOMO} \rightarrow \mathrm{LUMO}$ transition with a contribution of $96 \%$ and designated as single charge transfer (CT) transition with $\mathrm{phen} / \pi \rightarrow \mathrm{tpa} / \pi^{*}$ character. The most intense third excited state with the oscillator strength of 0.7794 is of also single component HOMO- $1 \rightarrow$ LUMO transition with $\mathrm{imp} / \pi \rightarrow \mathrm{tpa} / \pi^{*}$ character 

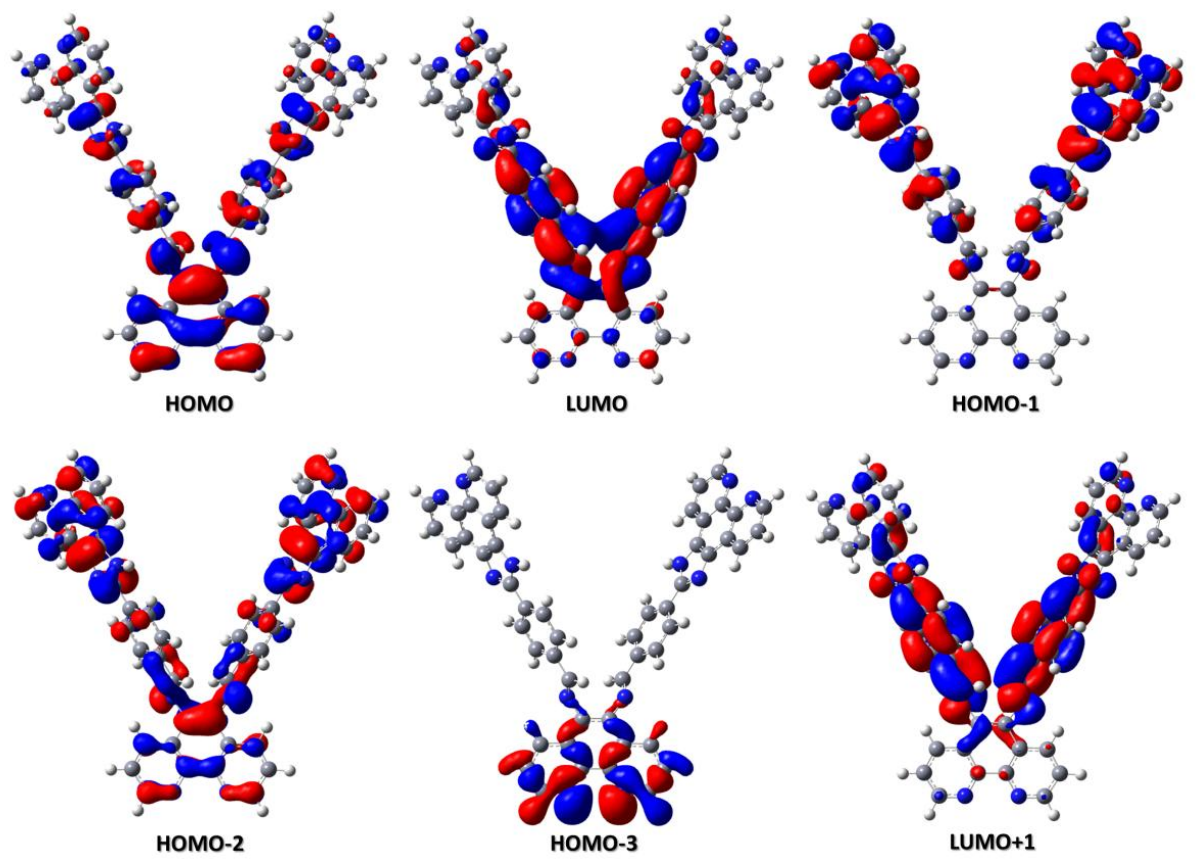

Figure 2. Ground state MOs of impap.

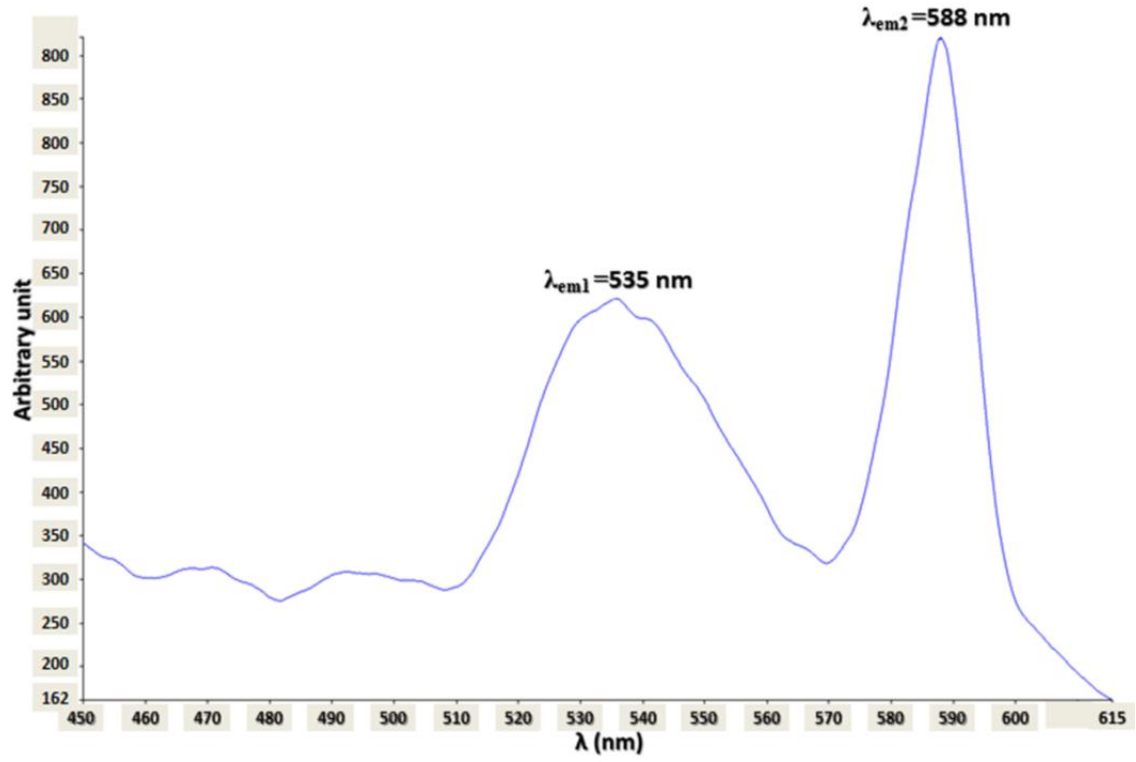

Figure 3. Solid state emission spectrum of impap.

Bull. Chem. Soc. Ethiop. 2017, 31(1) 
Table 2. Excited state parameters of impap.

\begin{tabular}{|c|c|c|c|}
\hline State & $\lambda(\mathrm{nm})$ & $f$ & Assign./Cont. \\
\hline 1 & 501 & 0.3705 & $\mathrm{H} \rightarrow \mathrm{L} / 96 \%$ \\
\hline 2 & 457 & 0.2765 & $\mathrm{H} \rightarrow \mathrm{L}+1 / 91 \%$ \\
\hline 3 & 393 & 0.7794 & $\mathrm{H}-1 \rightarrow \mathrm{L} / 96 \%$ \\
\hline 6 & 376 & 0.2165 & $\mathrm{H}-1 \rightarrow \mathrm{L}+1 / 96 \%$ \\
\hline 7 & 364 & 0.5841 & $\mathrm{H}-2 \rightarrow \mathrm{L}+1 / 89 \%$ \\
\hline
\end{tabular}

and most probably related to applied excitation $(387 \mathrm{~nm})$ for the emission spectrum. As a consequence, all calculated transitions of reasonably non-zero oscillator strengths and of higher wavelengths are assigned to strong CT transitions since they all originate from almost one $\mathrm{MO}$ transitions each of that is with varied MO composition as can be understood from Tables 1 and 2. The observed emission maxima are most probably related to vibration manifolds of the first excited state transition calculated at $382.4 \mathrm{~nm}$ to which the applied $387 \mathrm{~nm}$ excitation is assigned. Stokes shifts of $535 \mathrm{~nm}$ and $588 \mathrm{~nm}$ emission maxima pursuant to $387 \mathrm{~nm}$ excitation maximum are $148 \mathrm{~nm}$ and $201 \mathrm{~nm}$ respectively and are larger than most of imp derivatives previously reported [43-46].

\section{CONCLUSION}

A novel member of imidazo[4,5-f][1,10]phenanthroline family was prepared in five successive steps and characterized successfully by spectroscopic measurements. The ground state structure of impap was predicted by DFT/B3LYP/6-31G(d,p) level and the geometry was found nonplanar because of torsion around imine bonds. However, rigid planarity of impal units is thought to lead strong conjugation and fluorescence. Since both HOMO-1 and LUMO involving in the most intense CT transition responsible for the fluorescence reside completely on impal units that spread the entire unit. Stokes shifts of the two emission maxima were found to be larger than most of the related structures previously reported. In comparison to many other previously published imp derivatives, the compound prepared herein has a higher conjugative character through the entire molecule that gives rise to efficient fluorescence. The complete conjugation of the molecule may also result in high electrical properties. Furthermore, the compound may be considered as a potential candidate for DNA intercalation applications due to its larger planarity and aromaticity.

\section{REFERENCES}

1. Steck, E.A.; Day, A.R. Reactions of phenanthraquinone and retenequinone with aldehydes and ammonium acetate in acetic acid solution. J. Am. Chem. Soc. 1943, 65, 452-456.

2. Wang, R.; Wang, S.; Hu, N.-X. in Proceeding of the 85th CSC Conference and Exhibition, Canadian Society of Chemistry: Ottawa; 2002; p 527.

3. Wang, R.-Y.; Jia, W.-L.; Aziz, H.; Vamvounis, G.; Wang, S.; Hu, N.-X.; Popović, Z.D.; Coggan, J.A. 1-Methyl-2-(anthryl)-imidazo[4,5-f][1,10]-phenanthroline: A highly efficient electron-transport compound and a bright blue-light emitter for electroluminescent devices. Adv. Funct. Mater. 2005, 15, 1483-1487.

4. Xiao, S.; Yi, T.; Zhou, Y.; Zhao, Q.; Li, F.; Huang, C. Multi-state molecular switches based on dithienylperfluorocyclopentene and imidazo[4,5-f][1,10] phenanthroline. Tetrahedron 2006, 62, 10072-10078.

5. Bing, Y.J.; Leung, L.M.; Menglian, G. Synthesis of efficient blue and red light emitting phenanthroline derivatives containing both hole and electron transporting properties. Tetrahedron Lett. 2004, 45, 6361-6363. 
6. Gong, Y.; Wu, T.; Li, J.; Qin, J.; Wu, X.; Cao, R. Metal(II) complexes based on imidazo[4,5-f]-1,10-phenanthroline and bridging dicarboxylato ligands: Synthesis, characterization and photoluminescence. Z. Anorg. Allg. Chem. 2012, 638, 473-481.

7. Zhao, Q.; Liu, S.; Shi, M.; Li, F.; Jing, H.; Yi, T.; Huang, C. Tuning photophysical and electrochemical properties of cationic iridium(III) complex salts with imidazolyl substituents by proton and anions. Organometallics 2007, 26, 5922-5930.

8. Lee, J.-F.; Chen, Y.-C.; Lin, J.-T.; Wu, C.-C.; Chen, C.-Y.; Dai, C.-A.; Chao, C.-Y.; Chen, H.-L.; Liau, W.-B. Blue light-emitting and electron-transporting materials based on dialkylfunctionlized anthracene imidazophenanthrolines. Tetrahedron 2011, 67, 1696-1702.

9. Batista, R.M.F.; Costa, S.P.G.; Belsley, M.; Lodeiro, C.; Manuela, M.; Raposo, M.M.M. Synthesis and characterization of novel (oligo)thienyl-imidazo-phenanthrolines as versatile $\pi$-conjugated systems for several optical applications. Tetrahedron 2008, 64, 9230-9238.

10. Chao, H.; Yuan, Y.-X.; Ji, L.-N. Synthesis, characterization and third-order nonlinear optical properties of ruthenium(II) complexes containing 2-(4-nitrophenyl)imidazo[4, 5-f][1,10] phenanthroline. Transit. Metal. Chem. 2004, 29, 774-779.

11. Chao, H.; Li, R.-H.; Huang, Q.-W.; Ji, L.-N. Bis(4,4'-dimethyl-2,2'-bipyridine) ruthenium(II) complexes containing 2-arylimidazo-[4,5-f][1,10]phenanthroline: Syntheses, characterization and third-order nonlinear optical properties. Chinese J. Chem. 2002, 20, 1235-1240.

12. Chao, H.; Li, R.H.; Jiang, C.W.; Li, H.; Ji, L.N.; Li, X.Y. Mono-, di- and tetra-nuclear ruthenium(II) complexes containing 2,2'-p-phenylenebis(imidazo[4,5-f]phenanthroline): Synthesis, characterization and third-order non-linear optical properties. J. Chem. Soc., Dalton Trans. 2001, 1920-1926.

13. Cardinaels, T.; Ramaekers, J.; Nockemann, P.; Driesen, K.; Van Hecke, K.; Van Meervelt, L.; Lei, S.; De Feyter, S.; Guillon, D.; Donnio, B.; Binnemans, K. Imidazo[4,5-f]-1,10phenanthrolines: Versatile ligands for the design of metallomesogens. Chem. Mater. 2008, 20, 1278-1291.

14. Cardinaels, T.; Driesen, K.; Parac-Vogt, T.N.; Heinrich, B.; Bourgogne, C.; Guillon, D.; Donnio, B.; Binnemans, K. Design of high coordination number metallomesogens by decoupling of the complex-forming and mesogenic groups: Nematic and lamello-columnar mesophases. Chem. Mater. 2005, 17, 6589-6598.

15. Cardinaels, T.; Ramaekers, J.; Guillon, D.; Donnio, B.; Binnemans, K. A propeller-like uranyl metallomesogens. J. Am. Chem. Soc. 2005, 127, 17602-17603.

16. Cardinaels, T.; Ramaekers, J.; Driesen, K.; Nockemann, P.; Van Hecke, K.; Van Meervelt, L.; Goderis, B.; Binnemans, K. Thermotropic ruthenium(II)-containing metallomesogens based on substituted 1,10-phenanthroline ligands. Inorg. Chem. 2009, 48, 2490-2499.

17. Xiong, Y.; Ji, L.-N. Synthesis, DNA-binding and DNA-mediated luminescence quenching of Ru(II) polypyridine complexes. Coord. Chem. Rev. 1999, 185-186, 711-733.

18. Ji, L.-N.; Zou, X.-H.; Liu, J.-G. Shape- and enantioselective interaction of $\mathrm{Ru}(\mathrm{II}) / \mathrm{Co}(\mathrm{III})$ polypyridyl complexes with DNA. Coord. Chem. Rev. 2001, 216-217, 513-536.

19. Zhen, Q.-X.; Ye, B.-H.; Zhang, Q.-L.; Liu, J.-G.; Li, H.; Ji, L.-N.; Wang, L. Synthesis, characterization and the effect of ligand planarity of $\left[\mathrm{Ru}(\mathrm{bpy})_{2} \mathrm{~L}\right]^{2+}$ on DNA binding affinity. J. Inorg. Biochem. 1999, 76, 47-53.

20. Mariappan, M.; Maiya, B.G. Effects of anthracene and pyrene units on the interactions of novel polypyridylruthenium(II) mixed-ligand complexes with DNA. Eur. J. Inorg. Chem. 2005, 2164-2173.

21. Shavaleev, N.M.; Adams, H.; Weinstein, J.A. Platinum(II) imidazo[4,5-f]-1,10phenanthroline chloride and thiolate complexes: Synthesis and crystal structures. Inorg. Chim. Acta 2007, 360, 700-704. 
22. Selvi, P.T.; Palaniandavar, M. Spectral, viscometric and electrochemical studies on mixed ligand cobalt(III) complexes of certain diimine ligands bound to calf thymus DNA. Inorg. Chim. Acta 2002, 337, 420-428.

23. Wu, J.-Z.; Li, L.; Zeng, T.-X.; Ji, L.-N. Synthesis, characterization and luminiscent DNAbinding study of a series of ruthenium complexes containing 2-arylimidazo[f]1,10phenanthroline. Polyhedron 1997, 16, 103-107.

24. Wu, J.-Z.; Yang, G.; Chen, S.; Ji, L.-N.; Zhou, J.-Y.; Xu, Y. Intercalation into calf thymus DNA of 2-(4-arylphenyl)imidazo[4,5-f]-[1,10]phenanthroline (aryl = -OMe, $-\mathrm{NMe}_{2}$ or $-\mathrm{NO}_{2}$ ) in its bipyridyl ruthenium(II) complex. Inorg. Chim. Acta 1998, 283, 17-23.

25. Wang, X.-M.; Zhang, Y.; Zhao, T.-T.; Ding, L.-S. Synthesis and DNA interaction of a Sm(III) complex of a Schiff base derived from vanillin and L-tryptophan. Bull. Chem. Soc. Ethiop. 2011, 25, 197-207.

26. Kocak, A.; Yilmaz, H.; Faiz, O.; Andac, O. Experimental and theoretical studies on $\mathrm{Cu}(\mathrm{II})$ complex of $\mathrm{N}, \mathrm{N}^{\prime}$-disalicylidene-2,3-diaminopyridine ligand reveal indirect evidence for DNA intercalation. Polyhedron 2016, 104, 106-115.

27. Hu, Y.-M.; Wang, X.-M.; Pan, H.-Z.; Ding, L.-S. Interaction mode between methylene blueSm(III) complex and herring sperm DNA. Bull. Chem. Soc. Ethiop. 2012, 26, 395-405.

28. Turro, C.; Bossman, S.H.; Jenkins, Y.; Barton, J.K.; Turro, N.J. Proton transfer quenching of the MLCT excited state of $\mathrm{Ru}(\mathrm{phen})_{2} \mathrm{dppz}^{2+}$ in homogeneous solution and bound to DNA. $J$. Am. Chem. Soc. 1995, 117, 9026-9032.

29. Olson, E.J.C.; Hu, D.; Hormann, A.; Jonkman, A.M.; Arkin, M.R.; Stemp, E.D.A.; Barton, J.K.; Barbara, P.F. First observation of the key intermediate in the "light-switch" mechanism of $\left[\mathrm{Ru}(\mathrm{phen})_{2} \mathrm{dppz}\right]^{2+}$.J. Am. Chem. Soc. 1997, 119, 11458-11467.

30. Rajarajeswari, C.; Ganeshpandian, M.; Palaniandavar, M.; Riyasdeen, A.; Akbarsha, M.A. Mixed ligand copper(II) complexes of 1,10-phenanthroline with tridentate phenolate/pyridyl/(benz)imidazolyl Schiff base ligands: Covalent vs non-covalent DNA binding, DNA cleavage and cytotoxicity. J. Inorg. Biochem. 2014, 140, 255-268.

31. Irfan, A. Influence of the substitution on the electronic properties of perylene-3,4:9,10bis(dicarboximides): Density functional theory study. Bull. Chem. Soc. Ethiop. 2014, 28, 101-110.

32. Frisch, M.J.; Trucks, G.W.; Schlegel, H.B.; Scuseria, G.E.; Robb, M.A.; Cheeseman, J.R.; Scalmani, G.; Barone, V.; Mennucci, B.; Petersson, G.A.; Nakatsuji, H.; Caricato, M.; Li, X.; Hratchian, H.P.; Izmaylov, A.F.; Bloino, J.; Zheng, G.; Sonnenberg, J.L.; Hada, M.; Ehara, M.; Toyota, K.; Fukuda, J.; Hasegawa, R.; Ishida, M.; Nakajima, T.; Honda, Y.; Kitao, O.; Nakai, H.; Vreven, T.; Montgomery, J.A., Jr.; Peralta, J.E.; Ogliaro, F.; Bearpark, M.; Heyd, J.J.; Brothers, E.; Kudin, K.N.; Staroverov, V.N.; Kobayashi, R.; Normand, J.; Raghavachar, K.; Rendell, A.; Burant, J.C.; Iyengar, S.S.; Tomasi, J.; Cossi, M.; Rega, N.; Millam, J.M.; Klene, M.; Knox, J.E.; Cross, J.B.; Bakken, V.; Adamo, C.; Jaramillo, J.; Gomperts, R.; Stratmann, R.E.; Yazyev, O.; Austin, A.J.; Cammi, R.; Pomelli, C.; Ochterski, J.W.; Martin, R.L.; Morokuma, K.; Zakrzewski, V.G.; Voth, G.A.; Salvador, P.; Dannenberg, J.J.; Dapprich, S.; Daniels, A.D.; Farkas, Ö.; Foresman, J.B.; Ortiz, J.V.; Cioslowski, J.; Fox, D.J. Gaussian 09, Revision A.1, Gaussian Inc.: Wallingford CT; 2009.

33. Al-Sehemi, A.G.; Al-Amri, R.S.A.A.; Irfan, A. Synthesis, characterization and density functional theory investigations of monoacyl aniline derivatives. Bull. Chem. Soc. Ethiop. 2014, 28, 111-120.

34. Al-Sehemi, A.G.; Irfan, A.; Asiri, A.M. Red and yellow color aspects of compound 3dicyclopropylmethylene-5-dicyanomethylene-4-diphenylmethylenetetrahydrofuran-2-one: Chromism effect. Chin. Chem. Lett. 2014, 25, 609-612.

35. Abbas, G.; Al-Rashida, M.; Irfan, A.; Rana, U.A.; Shakir, I. -612 J. Struct. Chem. 2014, 55, 30-37. 
36. Irfan, A.; Muhammad, S.; Al-Sehemi, A.G.; Al-Assiri, M.S.; Kalam, A.; Chaudhry, A.R. The effect of anchoring groups on the electro-optical and charge injection in triphenylamine derivatives@ $\mathrm{Ti}_{6} \mathrm{O}_{12}$.J. Theor. Comput. Chem. 2015, 14, 1550027-1550039.

37. Irfan, A.; Zhang, J.; Chang, Y. Theoretical investigations of the charge transfer characteristics in dichlorotitanium phthalocyanine $\left(\mathrm{TiCl}_{2} \mathrm{Pc}\right)$ and tin phthalocyanine $(\mathrm{SnPc})$. Chem. Phys. Lett. 2009, 483, 143-146.

38. O'Boyle, N.M.; Tenderholt, A.L.; Langner, K.M. cclib: A library for package-independent computational chemistry algorithms. J. Comp. Chem. 2008, 29, 839-845.

39. Gorelsky, S.I. SWizard Program, Revision, 2010. Available at: http://www.sg-chem.net/.

40. Gorelsky, S.I.; Lever, A.B.P. Electronic structure and spectra of ruthenium diimine complexes by density functional theory and INDO/S. Comparison of the two methods. $J$. Organomet. Chem. 2001, 635, 187-196.

41. Calucci, L.; Pampaloni, G.; Pinzino, C.; Prescimone, A. Transition metal derivatives of 1,10-phenanthroline-5,6-dione: Controlled growth of coordination polynuclear derivatives. Inorg. Chim. Acta 2006, 359, 3911-3920.

42. Bodige, S.; MacDonnell, F.M. Synthesis of free and ruthenium coordinated 5,6-diamino1,10-phenanthroline. Tetrahedron Lett. 1997, 38, 8159-8160.

43. Jayabharathi, J.; Perumal, M.V.; Thanikachalam, V. Photophysical and computational studies of novel heterocyclic imidazole derivatives containing trifluoromethyl group substituent. Spectrochim. Acta Part: A 2012, 95, 497-504.

44. Jayabharathi, J.; Thanikachalam, V.; Sathishkumar, R.; Jayamoorthy, K. Physico-chemical studies of fused phenanthrimidazole derivative as sensitive NLO material. Spectrochim. Acta Part: A 2013, 101, 249-253.

45. Jayabharathi, J.; Thanikachalam, V.; Perumal, M.V. Photophysical studies of fused phenanthrimidazole derivatives as versatile $\pi$-conjugated systems for potential NLO applications. Spectrochim. Acta Part: A 2012, 92, 113-121.

46. Jayabharathi, J.; Thanikachalam, V.; Perumal, M.V. Characterization, photophysical and DFT calculation study on 2-(2,4-difluorophenyl)-1-(4-methoxyphenyl)-1H-imidazo[4,5f] $[1,10]$ phenanthroline ligand. Spectrochim. Acta Part: A 2012, 95, 614-621. 